University of Nebraska - Lincoln

DigitalCommons@University of Nebraska - Lincoln

Faculty Publications from the Harold W. Manter Laboratory of Parasitology

10-1959

\title{
Studies on the Helminth Fauna of Alaska. XXXVI. Parasites of the Wolverine, Gulo gulo L., with Observations on the Biology of Taenia twitchelli Schwartz, 1924
}

Robert L. Rausch

Arctic Health Research Center, rausch@u.washington.edu

Follow this and additional works at: https://digitalcommons.unl.edu/parasitologyfacpubs

Part of the Parasitology Commons

Rausch, Robert L., "Studies on the Helminth Fauna of Alaska. XXXVI. Parasites of the Wolverine, Gulo gulo L., with Observations on the Biology of Taenia twitchelli Schwartz, 1924" (1959). Faculty Publications from the Harold W. Manter Laboratory of Parasitology. 583.

https://digitalcommons.unl.edu/parasitologyfacpubs/583

This Article is brought to you for free and open access by the Parasitology, Harold W. Manter Laboratory of at DigitalCommons@University of Nebraska - Lincoln. It has been accepted for inclusion in Faculty Publications from the Harold W. Manter Laboratory of Parasitology by an authorized administrator of DigitalCommons@University of Nebraska - Lincoln. 


\title{
The Journal of Parasitology
}

\begin{tabular}{lll}
\hline \hline Volume 45 & OCTOBER, 1959 & Number 5 \\
\hline \hline
\end{tabular}

STUDIES ON THE HELMINTH FAUNA OF ALASKA. XXXVI. PARASITES OF THE WOLVERINE, GULO GULO L., WITH OBSERVATIONS ON THE BIOLOGY OF TAENIA TWITCHELLI SCHWARTZ, 1924

\author{
Robert Rausch \\ Arctic Health Research Center, Public Health Service, \\ U. S. Department of Health, Education, and Welfare, \\ Anchorage, Alaska
}

Natural biotic relationships already had been severely disrupted in the United States by the time significant interest had developed in faunistic helminthology. Some mammalian species, particularly the larger carnivores, had been extirpated or were represented only by scattered individuals in the few remaining wilderness areas. Thus, it is not remarkable that the helminths of such species as the wolverine, Gulo gulo Linnaeus, have been little studied. Fortunately, however, much of arctic and subarctic North America has endured in its primitive state, and here it is still possible to undertake basic biological studies under undisturbed conditions.

A comparatively large series of wolverines has been examined in this laboratory since 1949, and the helminths commonly occurring in this mammal in Alaska have been identified. Supplemental observations have been made on the anatomy of Taenia twitchelli Schwartz, 1924, and new information has been acquired on the life cycle of this cestode. The results of this work are reported herein.

MATERIALS AND METHODS

Eighty wolverine carcasses suitable for detailed examination were obtained from hunters and trappers, thus obviating the need for killing any animals solely for this investigation. The map (fig. 1) indicates locations from which the animals originated. Excepting one immature animal captured in July, all were taken during the colder months (October through May).

After first being isolated in tap water, the cestodes were fixed in hot 10 percent formalin, dehydrated in ethanol, cleared in terpineol, and prepared as permanent mounts. The nematodes were fixed in hot 70 percent ethanol, cleared in lactophenol, and studied unmounted. To establish experimental infections, eggs were taken from gravid segments of living cestodes and, by means of a pipette, introduced into the stomachs of experimental animals in a state of ether-induced anesthesia. Tissues collected from such animals were fixed in 10 percent formalin, embedded by the paraffin method, and sections were stained in hematoxylin-eosin.

\section{RESULTS}

Helminths were found in 69 (86 percent) of the 80 wolverines. Each species is discussed separately below.

$$
\text { TREMATODA }
$$

\section{Genus Alaria Schrank, 1788}

Alaria sp.: Fecal smears from a captive wolverine were examined daily for 7 weeks in connection with an experimental Taenia infection. Two trematode eggs were observed in one smear and, 39 days later, when the animal was autopsied, a

Received for publication April 17, 1959. 


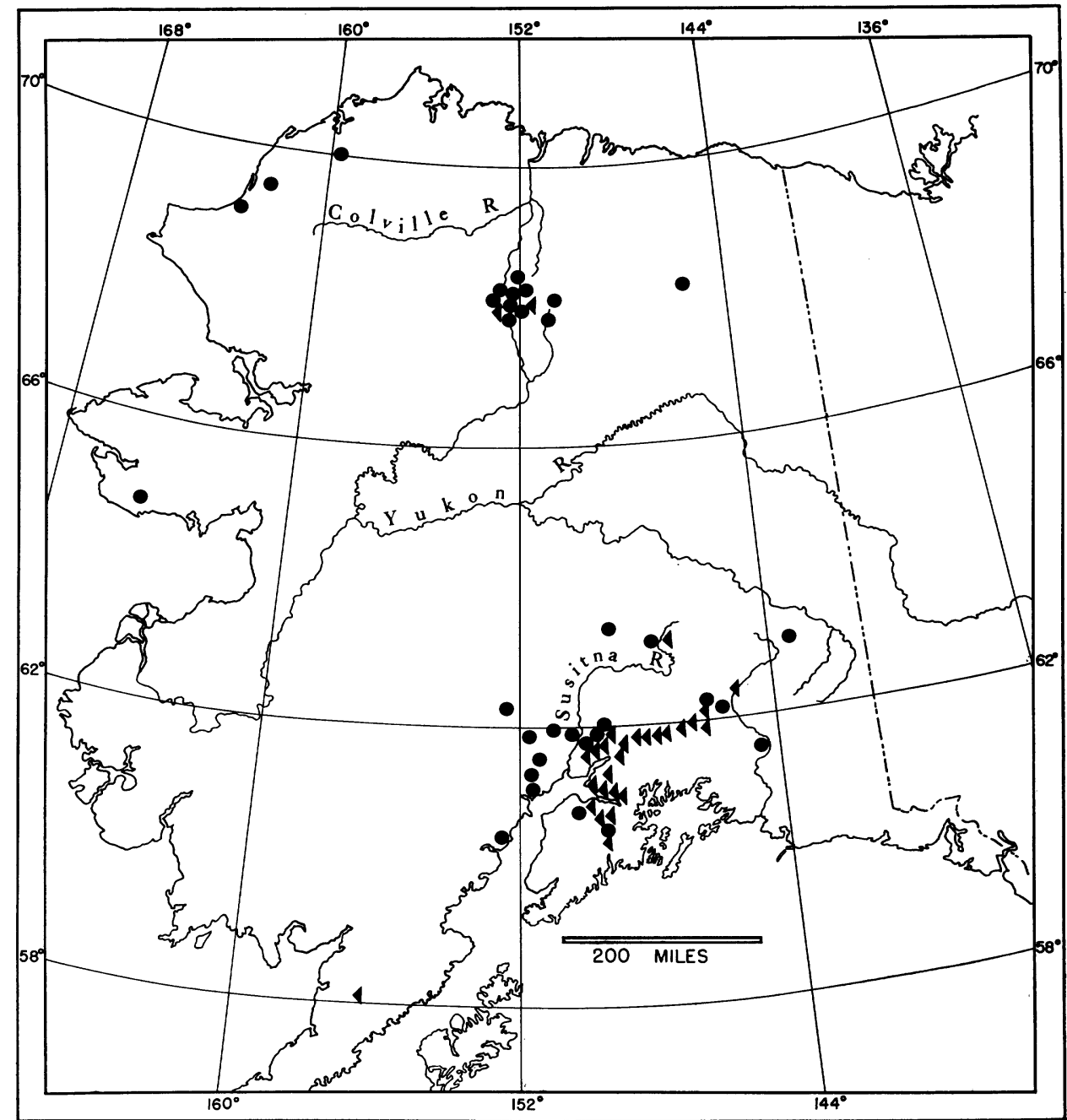

FIGURE 1. Map of Alaska, showing locations from which wolverines (circles) and porcupines (triangles) were obtained.

single trematode of the genus Alaria was found in the small intestine. This wolverine, not included in the above total, had been in captivity for about 2 years, during which time its diet precluded accidental infection by helminths.

The trematode differs morphologically from the known species of Alaria, none of which has been reported from wolverines, but a detailed study is deferred until additional material can be obtained.

\section{CESTODA}

Genus Mesocestoides Vaillant, 1863

Mesocestoides kirbyi Chandler, 1944: This species was collected from 2 (2.5 percent) of the 80 wolverines, and of these, one captured near Willow, south-central Alaska, had 2 cestodes similar in size to specimens from coyotes, Canis latrans Say, in Alaska. Ten smaller strobilae were found in a second wolverine, killed near Moose Pass, on the Kenai Peninsula. M. kirbyi is the only species of the genus 
known to occur in mammals in Alaska; material from canine hosts has been studied by Voge (1955). Species of Mesocestoides have not previously been recorded from wolverines.

\section{Genus Taenia Linnaeus, 1758}

Taenia twitchelli Schwartz, 1924: T. twitchelli was found in 60 wolverines (75 percent). In 27 infected animals these cestodes ranged in number from 1 to 61 , with an average of 17 . The life cycle and host relationships of $T$. twitchelli are discussed below.

\section{NEMATODA}

Genus Trichinella Railliet, 1895

Trichinella spiralis (Owen, 1835): Larval nematodes identified as T. spiralis were found in 19 (49 percent) of 39 wolverines appropriately examined. The occurrence of $T$. spiralis in this and other species of mammals in Alaska has been discussed elsewhere (Rausch et al, 1956).

\section{Genus Molineus Cameron, 1923}

Molineus patens (Dujardin, 1845): A single male specimen of this trichostrongyle was obtained from the small intestine of a wolverine killed near Willow and, although $M$. patens has been reported from other mustelids, this appears to be the first North American record from this host. In Eurasia, Machul'skii (1953) found $M$. patens in one of 4 wolverines from Buriat-Mongolia.

\section{Genus Ascaris Linnaeus, 1758}

Ascaris devosi Sprent, 1952: One of the more common helminths observed, A. devosi was recorded from 17 (21 percent) of the wolverines. It was found in 12 (30 percent) of 39 animals from the Brooks Range, Arctic Alaska. The other 5 were collected farther south. Individual animals had from one to 13 ascarids, with an average of about 6 .

Although $A$. devosi is the only species of Ascaris known to occur in the wolverine in North America, the identity of the ascarids from this host in Eurasia appears to be questionable. Nematodes identified as $A$. columnaris Leidy, 1856 , have been reported by Oshmarin (1946; cited in Machul'skii, 1953) from wolverines in Buriat-Mongolia. Spasskii et al (1952) recorded A. columnaris from this host in the region of Lake Baikal, and Machul'skii (1953) found it in 1 of 4 animals examined in Buriat-Mongolia. As pointed out by Sprent (1952), the morphological differences between $A$. devosi and $A$. columnaris might have been overlooked, and $A$. devosi may actually be the species occurring in Eurasian wolverines. Sprent (1952) also reviewed the status of other species of ascarids that have been reported from various mustelids in Eurasia.

Sprent (1953) concluded that an intermediate host (rodent) may be obligatory in the life cycle of $A$. devosi. In Alaska, both microtine rodents and smaller species of sciurids might serve as intermediate hosts of this nematode.

Genus Physaloptera Rudolphi, 1819

Physaloptera torquata Leidy, 1856: P. torquata was recorded from only 4 wolverines ( 5 percent), all from the Brooks Range region. One was taken near Anak- 
tuvuk Pass, and 3 were killed in the taiga biome near Arctic Village. One of the latter contained 17 specimens, the maximum seen in a single animal.

Although known to occur in other North American species of mustelids farther to the south, this is the first record of $P$. torquata from the wolverine. $P$. sibirica Petrov and Gorbunov, 1931, has been reported from wolverines in Eurasia (Oshmarin, 1946; Spasskii et al, 1952).

\section{Observations on Taenia twitchelli}

T. twitchelli was described by Schwartz (1924) from larvae found in the lungs and pleural cavities of a porcupine, Erethizon dorsatum myops Merriam, from Ophir, Alaska. A description of the adult stage was later provided by McIntosh (1938), who obtained specimens from a wolverine killed at Rapids, east-central Alaska. There are no further published records of the occurrence of this cestode.

I. The Adult Cestode

McIntosh (1938) remarked that his 3 cestodes were contracted, did not stain well, and also lacked gravid segments. It therefore seems desirable to provide a more complete description of this tapeworm.

There is an unusual tendency for strobilae of $T$. twitchelli to contract, making it difficult to obtain specimens suitable for detailed study. Those dying in situ in the host are usually so contracted as to convey the impression that $T$. twitchelli differs morphologically from its congeners much more than is actually the case. The following description of the adult stage is based on specimens removed alive, allowed to relax, and fixed. Complete relaxation of the anterior portion of the strobila often cannot be accomplished, even under the most favorable conditions.

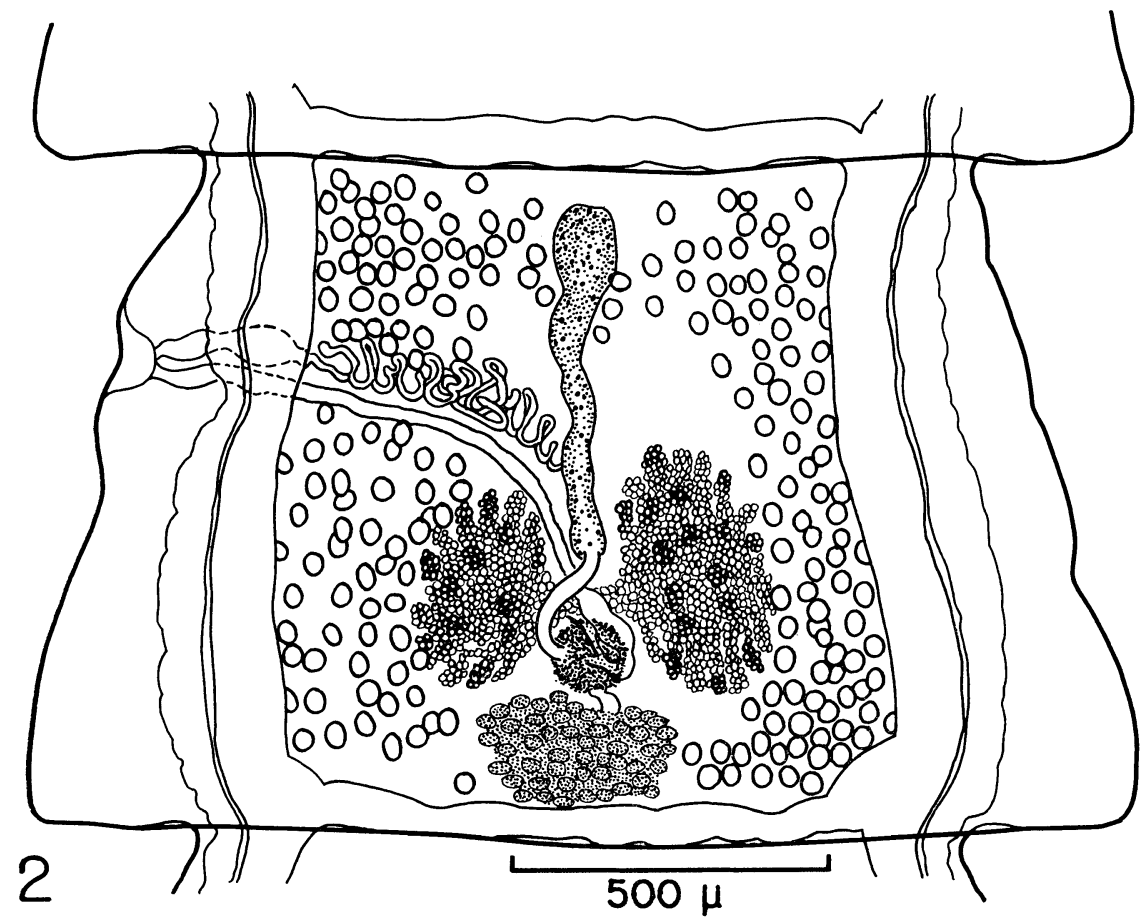

FIGURE 2. Mature segment of Taenia tzitchelli, ventral view. 


\section{Taenia twitchelli Schwartz, 1924 (figs. 2-4)}

Diagnosis: Strobila up to $210 \mathrm{~mm}$ long, with a maximum of 120 segments. Anterior segments wider than long; in partially contracted strobilae this anterior region comprises as much as $1 / 4$ of strobilar length, and may contain more than half the total number of segments. Length/ width ratio of segments increases toward posterior end of strobila. Mature segments trapezoidal and slightly longer than wide; gravid segments 2 to 3 times as long as wide. Maximum width attained in pre-gravid segments. Strobilar margins markedly serrate, particularly in region of mature segments. Scolex relatively small, measuring up to $1.2 \mathrm{~mm}$ in diameter; only slightly set off from unsegmented neck. Suckers small, about 265 microns in diameter. Rostellum armed with 32 to 36 hooks arranged in 2 rows; large and small hooks measure 200 to 212 microns and 156 to 168 microns in length, respectively. Genital pores irregularly alternate, situated in anterior half of segment. Genital ducts dorsal to longitudinal excretory canals. Elongate cirrus sac extends across ventral longitudinal excretory canal, and measures about 220 by 80 microns in mature segments. Vas deferens much coiled at proximal end of cirrus sac. Testes, about 200 per segment, average about 50 microns in diameter in mature segments; they are arranged in 2 lateral fields which may be confluent across anterior portion of segment, extending posteriad to level of posterior margin of vitelline gland, and some may slightly overlap ventral longitudinal excretory canals. Vagina opens into genital atrium just posterior to cirrus sac, runs transversely mediad, curving slightly posteriad, and enlarges to form small seminal receptacle between ovarian lobes and usually dorsal to Mehlis' gland. Ovary situated immediately posterior to center of segment; it consists of 2 reniform lobes, of which the larger is aporal. Vitelline gland lies posterior to ovary, in notch formed by margins of ovarian lobes; it approximates larger ovarian lobe in size and shape. Mehlis' gland about 100 microns in
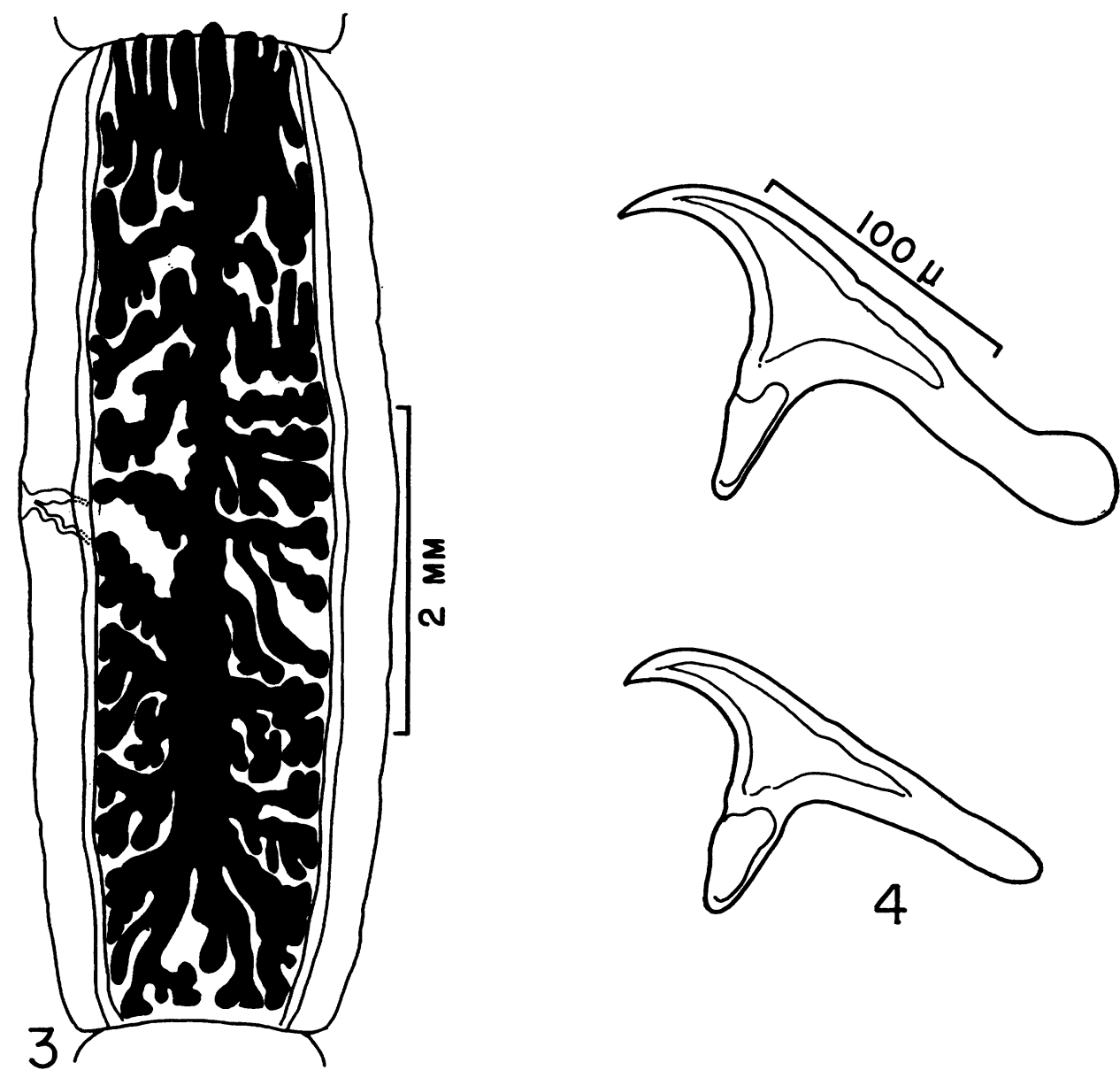

FIGURE 3. Gravid segment of $T$. twitchelli. FIGURE 4. Rostellar hooks of $T$. twitchell. 
diameter in mature segments. In terminal segments, gravid uterus usually has 10 to 12 lateral branches on each side; these subdivide, usually filling segment within limits of longitudinal excretory canals; branches at anterior end of gravid uterus usually extend slightly into preceding segment. Eggs measure from 30 to 36 microns in diameter (av. 34 microns).

Host: Wolverine, Gulo gulo Linnaeus.

Habitat: Duodenum.

Distribution: Boreal North America.

The characteristics of the rostellar hooks serve to distinguish the adult $T$. twitchelli from both T. mustelae Gmelin, 1790, and T. martis (Zeder, 1803), the only other species of Taenia known from mustelids in boreal regions (cf. Freeman, 1956).

T. twitchelli has been reported only from Alaska. I am indebted to Dr. Ian McTaggert Cowan, University of British Columbia, Vancouver, for permission to publish his record of this species from a wolverine killed on May 31, 1945, at Topaz Lake, Jasper National Park. It is probably a parasite of the wolverine throughout its range in North America.

II. The Larval Cestode

According to Schwartz (1924, p. 1), the description of T. twitchelli was based upon "... two detached cysticerci and a number of cysticerci attached to the lung tissue, some being attached directly to the lungs by means of a peduncle that penetrates into the lung tissue and others being attached indirectly, the peduncles of the individual cysticerci converging to a more or less common origin from which a stalk penetrates into the lung substance." Although these larvae had fully developed rostellar hooks, they were much smaller and differed in form from those I have obtained from both naturally and experimentally infected porcupines. Some of these differences may be due to the fact that Schwartz' specimens were preserved in brine.

Since 1953, 89 mammals representing 12 species, listed in table I, have been exposed to experimental infection. In addition, several animals received eggs later determined to have been non-infective. The smaller species were laboratory reared, but the porcupines, muskrats, and squirrels were trapped near Anchorage.

Development in Experimental Animals: Although the porcupine appears to be the natural intermediate host of $T$. twitchelli, larval development was ostensibly normal in experimentally infected animals of other species. Since rodents of species available in numbers for experimental use were found to resist infection, it was not possible to follow larval development to the infective stage in mammals of one kind. Animals killed by the infection were autopsied at once; otherwise experimental animals were killed at intervals for examination. The findings in selected animals are presented in chronological sequence. The various periods of lapsed time mentioned were computed from the day of exposure. No observations were made prior to the 9 th day in susceptible species.

9th day: Two voles, Microtus pennsylvanicus, died on the 9th day after each had received more than 1000 eggs. Macroscopically, the lungs showed many white foci, and no normalappearing tissue was visible. In slices of lung stained and cleared in toto, the larvae appeared as translucent, thin-walled bodies varying in shape from somewhat elongate to nearly sperical, and up to 500 microns in greatest length. In tissue sections, they appeared oval to round in cross-section; the well-defined cuticle was lined by a thin layer of cells enclosing an acidophilic reticulum containing scattered cells of large size.

13th day: A porcupine that had received an entire gravid segment died on the morning of the 13th day. The pulmonary surfaces showed many white, subpleural foci, some of which appeared as discrete streaks up to $7 \mathrm{~mm}$ long (fig. 5). In some foci, larvae were visible immedi- 
ately below the pleura. Stained and cleared cross sections cut parallel with the pulmonary surface revealed that the focal lesions had resulted from larval migration toward the pleura; or, in the case of the streaks, along the pulmonary surfaces just beneath the pleura. At this time, the larvae were ovoid to pyriform in shape, and as much as $1.3 \mathrm{~mm}$ in length. They occurred singly at the more superficial ends of the streaks; when pyriform in shape, the larger (anterior) end was directed outward. The wall of the anterior end usually appeared somewhat thicker than in the remainder of the body. None had penetrated the pleura, although some had caused it to bulge slightly. Most of the larvae lay at the ends of leukocyte-filled tunnels they had made through the tissue, and were in contact with normal tissue through which they were making their way.

Table I. Results of feeding eggs of $T$. twitchelli to experimental animals.

\begin{tabular}{|c|c|c|}
\hline Species & Number exposed & Number infected \\
\hline \multicolumn{3}{|l|}{ Larval development ostensibly normal : } \\
\hline Ground squirrel, Citellus undulatus Pallas & 3 & 3 \\
\hline Red squirrel, Tamiasciurus hudsonicus (Erxleben) & 1 & 1 \\
\hline Brown lemming, Lemmus sibiricus (Kerr) & 7 & 2 \\
\hline Field vole, Microtus pennsylvanicus (Ord) & 2 & 2 \\
\hline Musk rat, Ondatra zibethicus (Linnaeus) & $\mathbf{5}$ & 5 \\
\hline Porcupine, Erethizon dorsatum (Linnaeus) & 7 & 7 \\
\hline \multicolumn{3}{|l|}{ Larval development inhibited or abnormal : } \\
\hline Hamster, Mesocricetus auratus Waterhouse & 4 & - \\
\hline Red-backed vole, Clethrionomys rutilus Pallas & 45 & - \\
\hline Tundra vole, Microtus oeconomus Pallas & 6 & - \\
\hline White rat, Rattus norvegicus (Berkenhout) & 2 & - \\
\hline White mouse, Mus musculus Linnaeus & 6 & 2 \\
\hline Rhesus monkey, Macaca mulatta Zimmermann & 1 & - \\
\hline
\end{tabular}

17th day: A red squirrel that had received a gravid segment behaved normally on the 15th day, showed signs of severe respiratory distress on the 16th day, and died in the afternoon of the 17th day. The pleural cavities contained a quantity of sero-sanguineous fluid in which 419 free larval vesicles were found. These, after becoming somewhat turgid in water, averaged about $10 \mathrm{~mm}$ in length, with a maximum length of $15 \mathrm{~mm}$. Nearly all had an irregular shape, due to the formation of buds (fig. 6). The walls of the vesicles showed small, disc-shaped aggre-

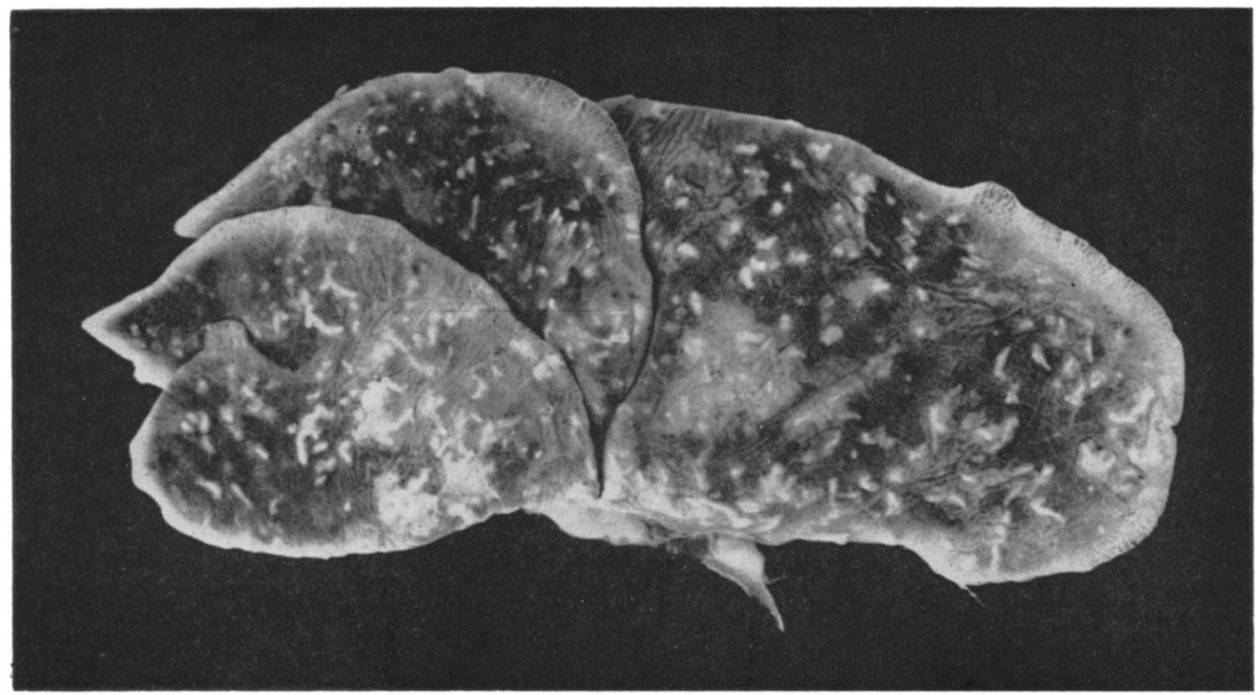

Figure 5. Lung of porcupine on 13th day after exposure, dorsal view; location of migrating larvae of $T$. twitchelli indicated by white foci.

gations of cells that were visible as small opacities when unstained. These aggregations, the primordia of the scolices, occurred at the apices of the buds, some of the largest of which already showed beginning invagination at the tip. A few vesicles protruded partially through the pleura, and both lungs showed areas of massive hemorrhage (fig. 7). A few larvae were found in the liver, but none had emerged. Sections showed a few also still deep within the pulmonary tissue; in these, the cuticle had a thickness of about 6 microns, and was lined by a layer of cells about 12 microns thick. The lumina of these larvae were filled by a delicate, acidophilic reticulum. The 


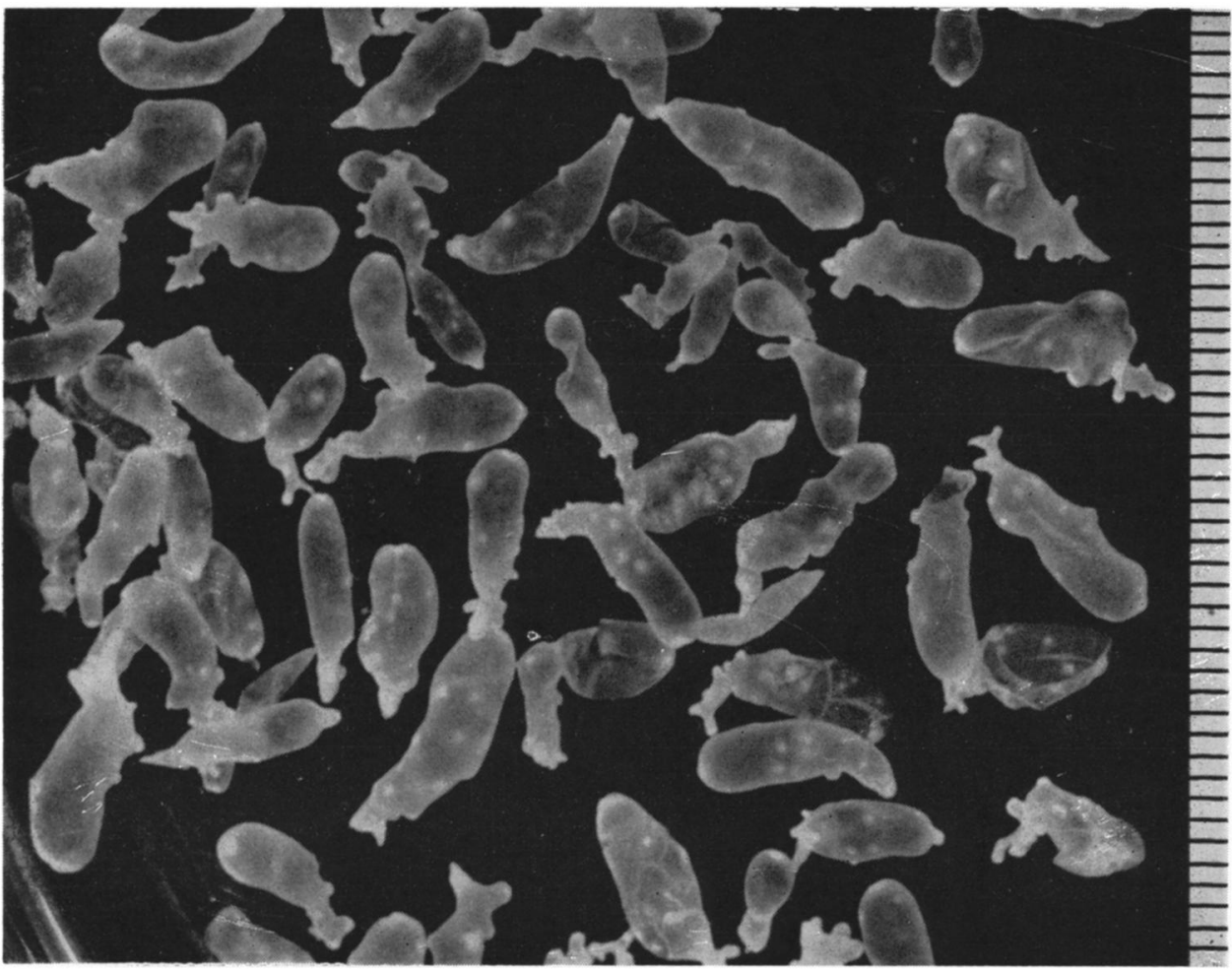

Figure 6. Larvae of $T$. twitchelli from the pleural cavities of a red squirrel on the 17th day; primordia of scolices and early buds visible. (Each space of scale has value of $1 \mathrm{~mm}$.)

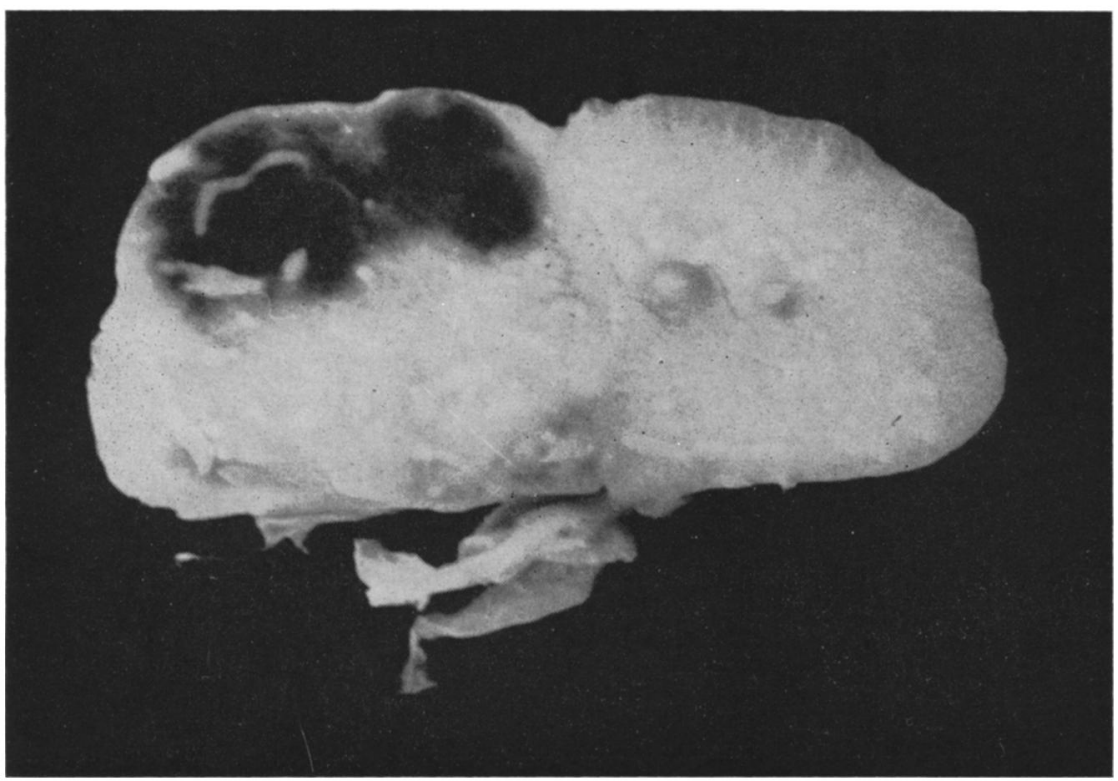

FIGURE 7. Lung of red squirrel on 17 th day, dorsal view, showing hemorrhagic area and superficial lesions caused by emergence of larvae of $T$. twitchelli. 
larvae in the liver were identical in form to those in the lungs.

20th day: A large adult porcupine died on the 20th day after receiving several thousand eggs. Macroscopicaliy, the lungs appeared to be involved to about the same degree as in the porcupine that died on the 13th day, but the pleura was considerably thickened. Numerous larvae protruded through the pleura, and 200 were found free in the pleural cavities; these averaged smaller than those from the red squirrel mentioned above, but the buds were somewhat more advanced in development. Larvae were numerous in the liver of this animal, and often were found in small, blood-filled cavities. None had penetrated the hepatic peritoneum. Tissue sections showed larvae to be still numerous in the lungs.

24th day: In a porcupine that died on the 24th day, the lungs were involved to about the same extent as those from the porcupines on the 13th and 20th days, but the effects of the chronic course of the infection were more evident. The pleura was so much thickened and so opaque that the underlying lesions were hardly visible. The right lung was the more severely affected, and the right pleural cavity contained a large, stratified blood-clot as well as $30 \mathrm{ml}$ of sero-sanguineous fluid. There were blood-clots in the left pleural cavity also, but little fluid. Exclusive of those trapped in the clots, 91 free larvae were found in the pleural cavities. They resembled those found on the 20 th day, but with buds more advanced in development. Many larvae remained within the lungs.

60th day: A muskrat that had received small numbers of eggs (fed in the feces of an infected wolverine) over a period of 4 consecutive days died on the 60 th day after the first feeding. The lungs showed many white foci, and the pleura was much thickened. A few larvae were partially emerged from the ventral pulmonary surfaces, and 678 free vesicles completely filled the pleural cavities. The larvae ranged up to $20 \mathrm{~mm}$ in length and, in addition to buds in various stages of development, some had produced secondary vesicles by means of exogenous proliferation (fig. 8). Many of the latter had already become detached from the primary vesicles, and

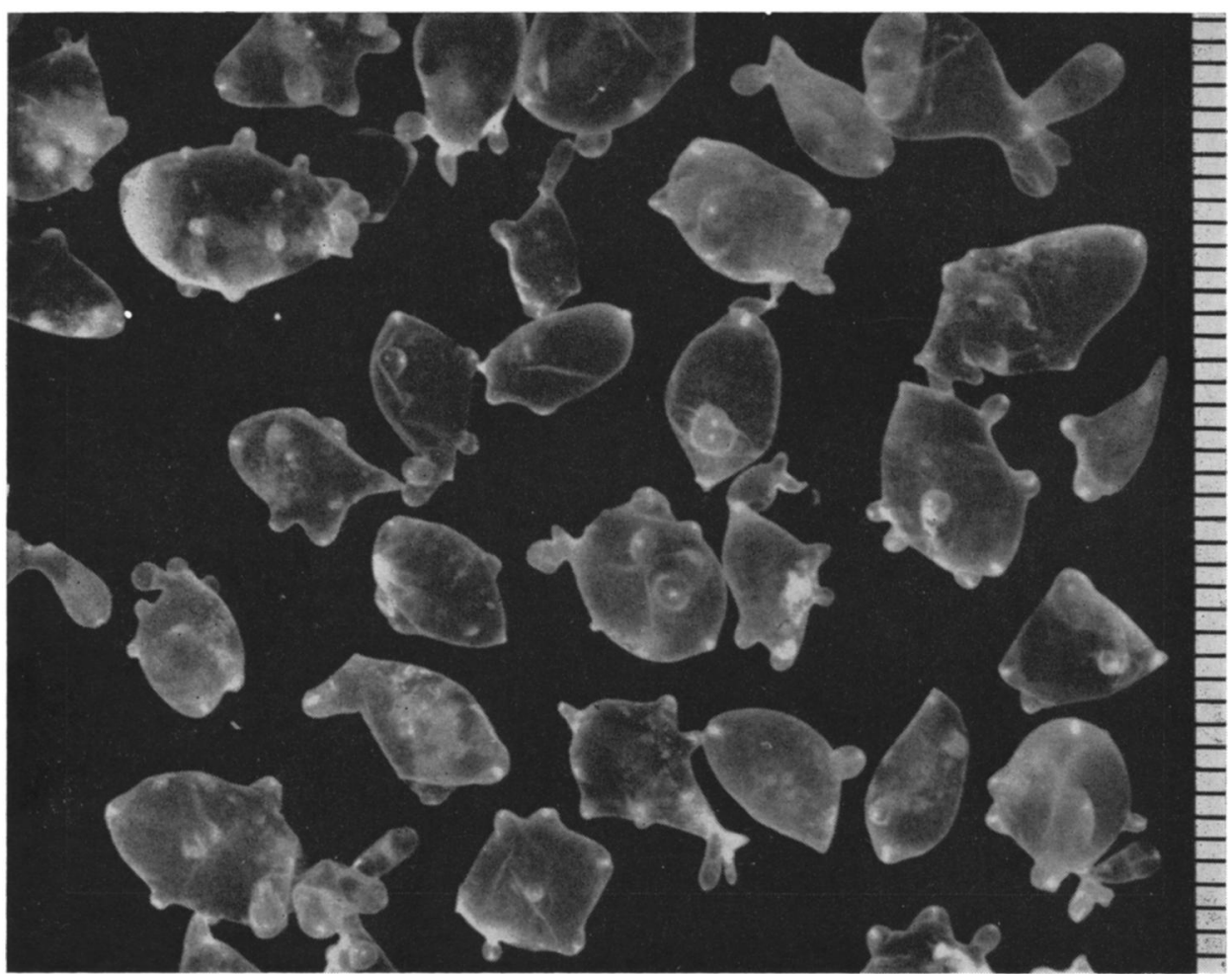

Figure 8. Larvae of $T$. twitchelli from the pleural cavities of a muskrat on the 60th day after exposure; buds well advanced, some larvae having produced secondary vesicles. (Each space of scale has value of $1 \mathrm{~mm}$.)

were undergoing independent development. Most did not yet show the primordia of scolices. The most advanced buds on the larger primary vesicles had deep, apical invaginations (as much as 600 microns in depth), but the formation of rostellar hooks was not yet apparent. Sections disclosed a few apparently immobilized vesicles, surrounded by a narrow zone of connective tissue, still deep within the pulmonary tissue. Although irregular in shape, these had produced no buds. Ten larvae, resembling the largest from the pleural cavities, were found in the abdominal cavity. 
63rd day: A single vesicle was found in the pleural cavity of a brown lemming killed on the 63rd day. Although measuring only $6 \mathrm{~mm}$ in diameter, it had 7 short peduncles, each with a well-developed scolex and fully developed hooks.

67th day: A muskrat received eggs on 2 consecutive days, and died on the 67th day after the first feeding. This death was not definitely attributable to the infection, since few larvae were present. Thirteen large vesicles were found in the pleural cavities; 8 of these were free, and 5 were attached to the pulmonary pleura in the vicinity of the hili. All possessed large scolices on long peduncles, and the rostellar hooks were fully developed. Nine similar larvae were found in the abdominal cavity.

91st day: Another muskrat given eggs on 2 successive days was examined on the 91st day after the first feeding. Macroscopically, the lungs appeared normal, and the pleural cavities were found to contain 2 vesicles with 2 and 6 scolices, respectively. These were fed to a captive wolverine, and not studied in detail.

94th day: A single larva with 3 mature scolices was found in the pleural cavity of a brown lemming examined on the 94th day.

96th day: A muskrat that had received eggs over a period of 4 successive days was killed on the 96th day. Macroscopically, the lungs of this animal appeared normal. Of the 10 larvae found in the pleural cavities, 1 was attached to the tissue near the hilus, on the left side, and 9 were free. These larvae each had several elongate peduncles, and the rostellar hooks were fully developed (fig. 9). Nine additional larvae were found in the abdominal cavity.

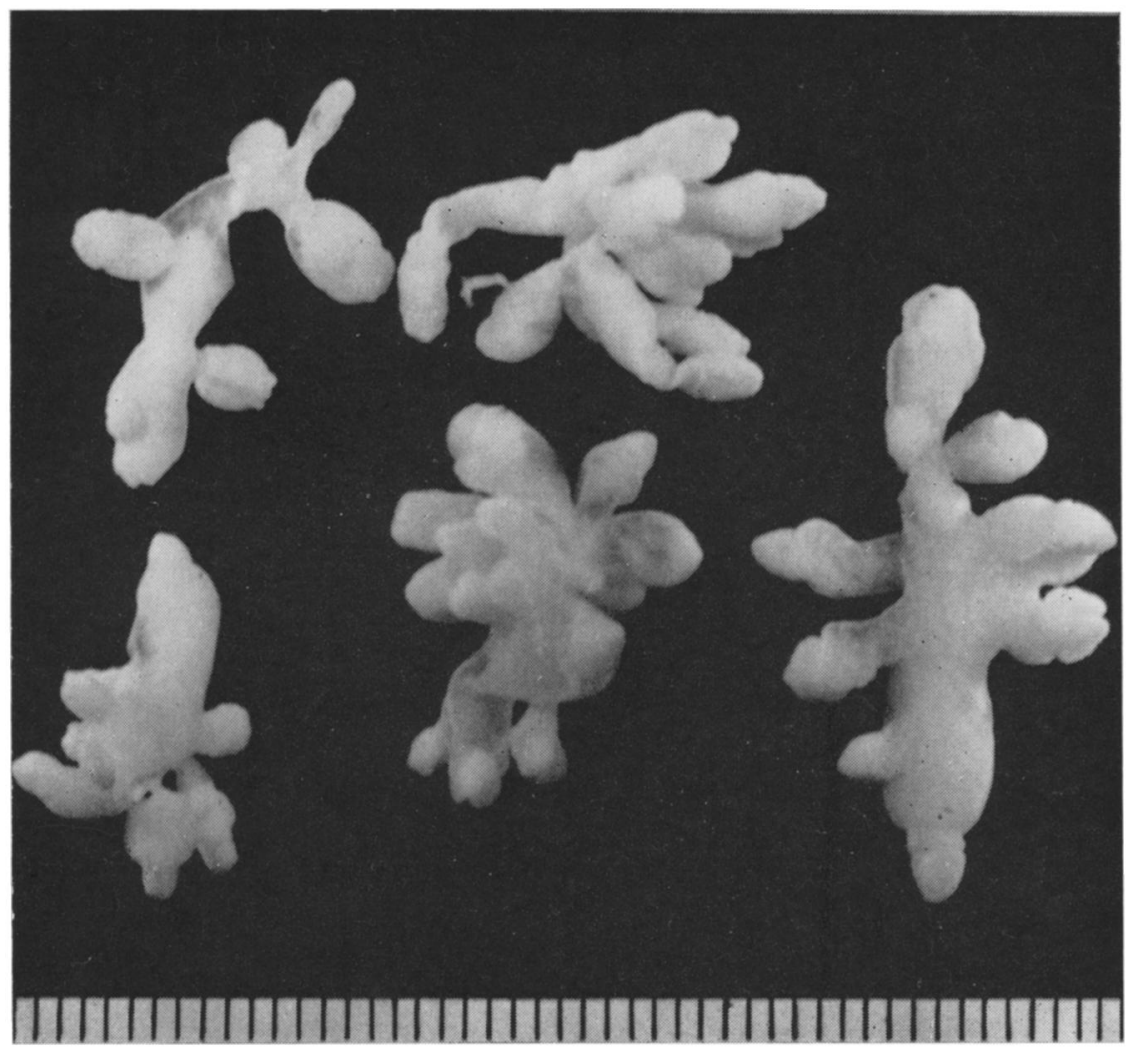

FIgURE 9. Infective larvae of $T$. twitchelli from pleural cavities of a muskrat on the 96th day after exposure. (Each space of scale has value of $1 \mathrm{~mm}$.)

109th day: On the 109th day, a ground squirrel died of pulmonary disease caused, at least primarily, by the infection. It showed signs of severe respiratory distress on the 108th day, although its physical condition had deteriorated over a period of several weeks. Macroscopically, large portions of the lungs appeared atelectatic; numerous white foci were present, and the pleura was covered by a layer of fibrino-purulent exudate. Larval vesicles, 247 in number, completely filled the pleural cavities; these showed a wide range of developmental stages, with the largest measuring up to $27 \mathrm{~mm}$ in length. Some of the smaller vesicles showed only the early primordia of scolices, with no budding, and presumably had been produced by exogenous proliferation, while some were mature. A large larva was found within the pericardium, which was much thickened. Several with mature scolices were present in the abdominal cavity; one 
mass was attached near the base of the uterus, others were in the omentum and mesenteries, and some were free. One was attached retroperitoneally on the ventral surface of the psoas muscles. There was a general peritonitis, with adhesions between the liver and diaphragm. In the right axial region, a mass of larvae was found attached dorsal to the serratus dorsalis muscle. Tissue sections revealed a few large vesicles still in the lungs; these were surrounded by connective tissue. Budding was not noted. No larvae remained in the liver.

126th day: The lungs of a ground squirrel killed on the 126th day were macroscopically normal. Four larvae were found: 1 was embedded in muscle tissue near the aorta, dorsal to the heart; 1 was attached to the lower trachea; 1 was found free in the abdominal cavity; and 1 was in the pelvic cavity. All had long peduncles with mature scolices.

241st day: A porcupine given eggs on 2 successive days was killed on the 241 st day after the first feeding. The pulmonary pleura was thickened focally, and the affected areas had numerous projecting strands of fibrinous tissue. White, consolidated areas were observed peripherally when the lungs were cut. Three mature larvae were found in the pleural cavities.

Larvae in a Naturally Infected Porcupine: Fifty-five porcupines from various localities in Alaska (see fig. 1) were autopsied to obtain information on the occurrence of the larval cestode. Only 1, collected about 95 miles northeast of Anchorage by Mr. Edward Beeman, was found to be infected. This animal, killed on January 8 , 1959, was a young female weighing 12 pounds.

The pleural cavities contained 9 fully developed larvae, of which 8 were on the left side. Macroscopically, the right lung appeared normal; the lower portion of the diaphragmatic lobe of the left lung was firmly adhered along its costal surface to the parietal pleura, the basal borders of all 3 lobes having numerous fibrinous strands (fig. 10). Areas of thickened pleura, with considerable fibroblastic pro-

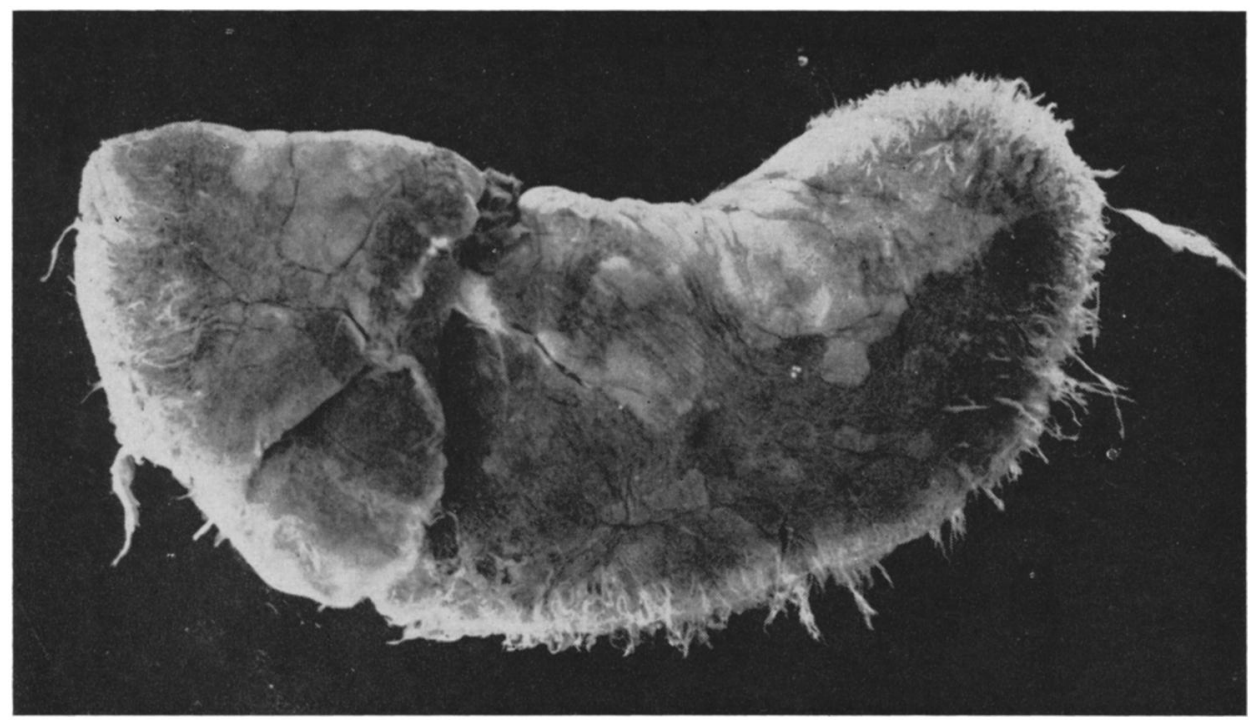

FIGURE 10. Lung of porcupine naturally infected with $T$. tweitchelli, showing fibrinous strands along borders (dorsal view).

liferation, were evident in sections of the left lung; focal areas of lymphocytic aggregation, apparently residual inflammatory effects of the infection, were present. The interstitial capillaries were severely congested, probably an immediately antemortem phenomenon. Only a few aggregations of lymphocytes were present in sections of the right lung.

These larvae differed in form from any observed in experimentally infected animals. All were quite elongate, and more or less cylindrical, measuring as much as $62 \mathrm{~mm}$ in length (fig. 11), and each had a single scolex. Superficially they re- 
sembled the mature cysticerci of $T$. hydatigena Pallas, 1766, although the vesicles were not so well developed. One was fed to a ferret, and 2 to a wolverine, in an effort to rear the adult cestode.

Non-Susceptible Animals Exposed to Infection: Attempts to infect mammals of several species were unsuccessful. Three series of red-backed voles were exposed, and one animal from each series was examined daily. Negative results

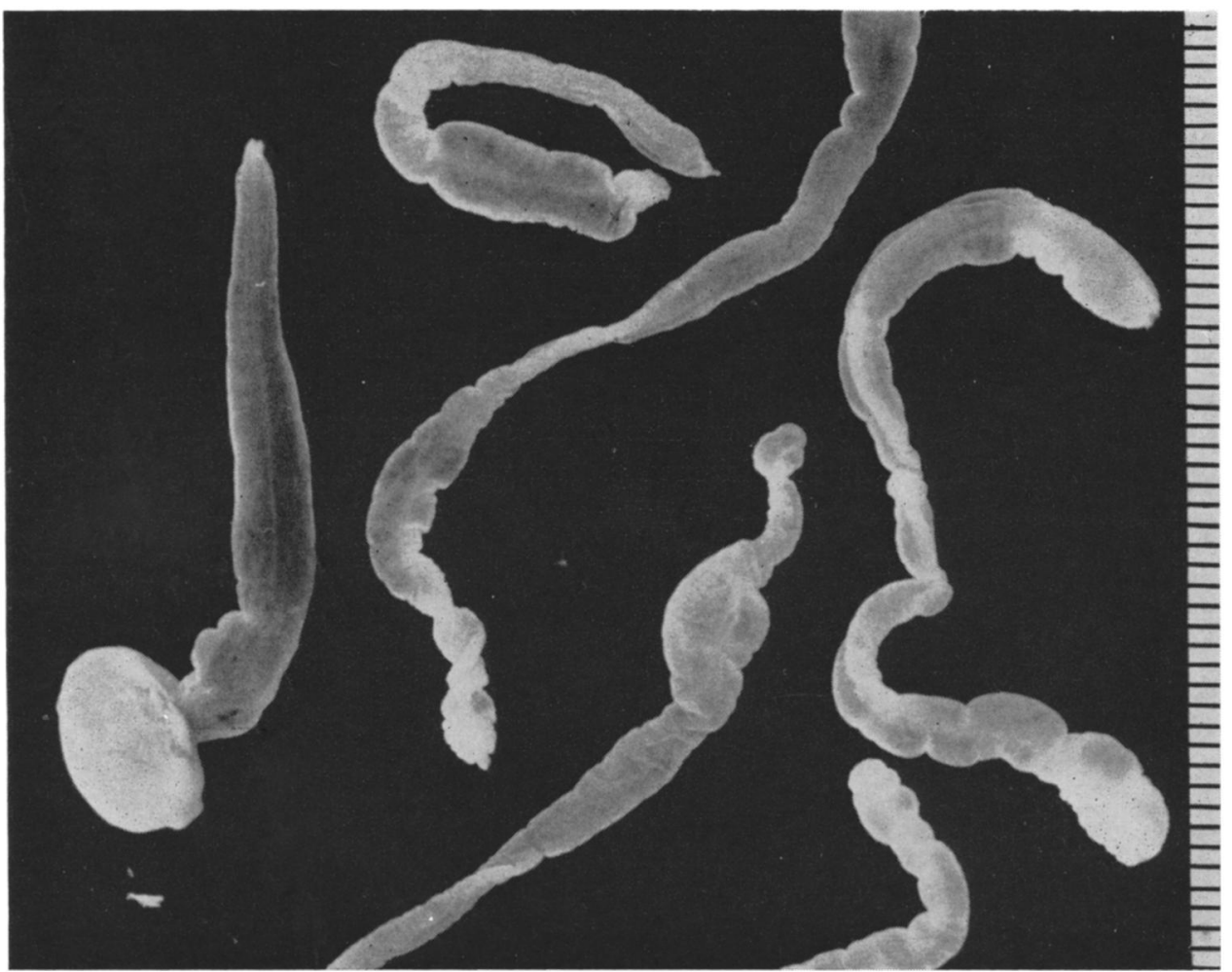

FIGURE 11. Infective larvae of $T$. twitchelli from pleural cavities of a naturally infected porcupine; scolex of one enclosed by mass of fatty tissue. (Each space of scale has value of $1 \mathrm{~mm}$.)

were obtained in the first series of 9 that had received about 600 eggs each. Fifteen animals in the second series were each given about 1000 eggs. On the 4th day after exposure, one vole exhibited rapid respiration, erected pelage, and reluctance to move. At autopsy the lungs were found to be severely congested. Three others died on the 5th day after having passed blood-stained fluid from the nostrils. The lungs of 2 of these were much congested, the pleural cavities contained small quantities of free blood, and one showed petechial hemorrhages on the surface of the liver. The third animal, partially eaten by its cage-mates, was not examined. Many atelectatic alveoli and areas of microscopic emphysema, marked interstitial and limited intra-alveolar hemorrhage, thrombosis of some vessels, as well as the previously mentioned congestion, were evident in tissue sections of the lungs of the latter 3. The liver of the one contained small, scattered, granulomatous lesions in which polymorphonuclear leukocytes were predominant. The central veins were 
congested, and the hepatic cells, having undergone degenerative changes, were granular in appearance in large areas. No larval cestodes were recognized in this material.

In the third series of 14 voles, each of which had received about 1000 eggs, 4 animals were severely ill on the 5th day. Two of the latter were killed for examination, and the others recovered. Tissue sections of the lungs resembled those from the previously discussed series. The animals that survived were examined only macroscopically.

The lungs of 2 hamsters killed on the $23 \mathrm{~d}$ day after having received several hundred eggs showed 2 and 4 macroscopically visible foci, respectively, which, in tissue sections, were found to be small, granulomatous lesions with necrotic centers, each surrounded by a zone of lymphocytes with a few eosinophils. These lesions presumably represented the loci of larvae overcome by the tissue reaction of the hosts. Similar lesions, some with foreign-body giant cells, were observed in the lungs of 2 tundra voles killed on the 28th day after exposure.

A young rhesus monkey which had received several thousand eggs (6 gravid segments) manifested no clinical evidence of infection. When examined on the 126th day, the liver and lungs were grossly negative, but sections of the latter revealed some rather large areas of granulomatous reaction, consisting of necrotic foci surrounded by polymorphonuclear leukocytes, lymphocytes, a few giant cells, and limited fibroblastic proliferation. No larvae were identified.

Two white mice, each receiving several hundred eggs, were examined on the $23 \mathrm{~d}$ day after exposure. Macroscopically, their lungs appeared normal. They had, respectively, 2 and 3 malformed larval vesicles, up to $3 \mathrm{~mm}$ in length, free in the pleural cavities. Sections showed a thickened pleura with a few small foci of leukocytic infiltration in the lungs, and, in the liver, small, granulomatous lesions in which it was impossible to identify any larvae. Four other white mice similarly exposed disclosed no larvae when examined on the 63d day. Nothing was found in 2 white rats which had received about 1000 eggs each.

Pathological Effects of the Larval Cestode: After entering the portal circulation, the onchospheres of $T$. twitchelli usually pass through the liver and localize in the lungs of the intermediate host. Compared with the larvae of other species of Taenia, the larval $T$. twitchelli is unusually pathogenic, the degree of pathogenicity manifested being proportional to the number of eggs ingested; a few larvae may cause recognizable changes in the lungs, and larger numbers can damage these organs so severely that death results. The liver is sometimes involved, but the infections so far observed in susceptible animals have not been sufficiently extensive to impair the function of this organ. In experimental animals, larvae have sometimes been observed in locations attainable only by means of the systemic circulation.

The gross pathological findings in susceptible animals have been described briefly under the section on larval development. The histopathological findings in the same animals are presented below.

The lungs of field voles on the 9th day contained many large foci of inflammatory reaction with extensive infiltration of polymorphonuclear leukocytes and lymphocytes, along with scattered eosinophils and foreign-body giant cells in some areas. Early fibroblastic proliferation was evident around some foci. Few alveoli appeared normal, and many contained erythrocytes; the focal pneumonitis was so extensive that the lungs had become essentially non-functional. 
Sections from the lungs of the red squirrel on the 17 th day disclosed few normal alveoli; most were either atelectatic, or no longer recognizable as such. Scattered throughout the lungs were extensive areas of pneumonitis ; large areas were infiltrated with polymorphonuclear leukocytes and lymphocytes. Erythrocytes were found throughout the tissue, and all vascular channels were much congested, some thrombosed as well. The diaphragmatic lobes had extensive areas of hemorrhage. Except for a few deeply-seated vesicles, the larvae had entered the pleural cavities; some of those remaining were in part surrounded by atelectatic alveoli, apparently compressed by the migrating larvae. Others were surrounded by a zone of leukocytic infiltration comprised of both polymorphonuclear leukocytes and lymphocytes. Focally, giant cells were numerous, as were scattered concentrations of macrophages with foamy cytoplasm. The pleural surfaces showed focal concentrations of leukocytes marking points of larval penetration, aggregations which consisted of lymphocytes and macrophages. Coagulated blood often was present around the openings in the pleura.

Severe diffuse pneumonitis characterized by marked edema was evident in the lungs of the porcupine on the 13th day. Larvae were numerous and usually surrounded by zones of polymorphonuclear leukocytes. Many alveoli were filled with erythrocytes, all vascular channels were much congested, and macrophages containing hemosiderin were scattered throughout the tissue. On the 20th day (porcupine) some larvae were surrounded by dense aggregations of polymorphonuclear leukocytes, while others, apparently migrating, were in contact with atelectatic alveoli. Hemosiderin-filled macrophages were abundant, many alveoli contained erythrocytes, and a purulent exudate was evident in some areas. In the liver, the rather severe fatty metamorphosis noted probably had resulted from nutritional deficiencies during captivity. The larvae in the liver were surrounded by wide zones of acute inflammatory reaction consisting almost entirely of polymorphonuclear leukocytes. On the 24th day (porcupine), few larvae were found in the lungs, which contained extensive areas of pneumonitis with both polymorphonuclear leukocytes and lymphocytes, many atelectatic alveoli, and numerous thrombosed vessels. The fibrosed and thickened pleura was covered by a layer of acute inflammatory exudate in which polymorphonuclear leukocytes predominated.

The changes seen in sections of the lungs of the muskrat on the 60th day were compatible with the longer duration of the infection. About one-half of the total volume of the lungs was occupied by apparently immobilized larvae surrounded by connective tissue. The adjacent alveoli were atelectatic, evidently a result of continuing larval growth. Other vesicles were surrounded in part by focal concentrations of mononuclear cells. There were scattered areas of focal pneumonitis, considerable interstitial hemorrhage, and thrombosis of the smaller vessels. The pleura appeared normal.

No histopathological changes were found in the lungs of the brown lemming on the $63 \mathrm{~d}$ day. The lungs of the muskrat that died on the 67 th day were congested and showed some interstitial hemorrhage and edema, but there was no indication that Taenia infection was the cause of death. No tissues were preserved from the muskrat killed on the 91 st day, nor from the lemming on the 94th day. Except for a few scattered aggregations of lymphocytes, the lungs were normal in the muskrat examined on the 96th day.

Sections of the lungs of the ground squirrel on the 109th day resembled in some details those from the porcupine on the 60th day. The surface of the edematous and thickened pleura was covered by an irregular layer of fibrino-purulent exudate. The inflammatory reaction was confined mainly to the pleural and subpleural areas, the latter showing extensive lymphocytic infiltration. The alveoli were characterized by atelectasis and considerable interstitial hemorrhage. The vascular channels were congested, and the bronchioles contained an amorphous eosinophilic material. Those larvae remaining in the lungs were surrounded by a zone of connective tissue adjacent to which were focal aggregations of mononuclear leukocytes.

The lungs of the porcupine on the 241 st day contained areas of adenomatous proliferation, with associated atelectasis and minimal inflammation. Whether the adenomatous tumor was malignant or whether it was in any way connected with the Taenia infection was not determined. No lesions definitely attributable to the infection were identified.

\section{The Host Relationships of T. twitchelli}

The composition of the diet of wolverines in Alaska is largely unknown, save for reports in the literature that they feed upon the carrion of various species of ruminants. In the course of the present work, records on stomach-contents were kept. A number of the wolverines had remained in traps for some time and, consequently, their stomachs were empty. Of the 20 stomachs containing identifiable material, 12 (60 percent) held remains of moose or caribou, presumably carrion since the wolverines had been taken where carcasses of these deer were known to be available. Remains of porcupines, in 2 cases only the quills, were found in 3 (15 percent) of the stomachs. A vole, Microtus sp., and a ground squirrel, Citellus undulatus Pallas, were found in the young wolverine killed during July. 
The following animals were also recorded from wolverines killed in the winter: snowshoe hare, Lepus americanus Erxleben; red-backed vole, Clethrionomys rutilus Pallas; magpie, Pica pica (Linnaeus); unidentified hawk; unidentified bird; and remains of fish.

The high prevalence of $T$. twitchelli in wolverines indicates that the larval stage occurs in a species of mammal eaten regularly. The finding of porcupine remains in 3 of 20 stomachs indicates the importance of the porcupine as a source of food. Porcupines, distributed widely and at times locally abundant in Alaska, would seem to be particularly vulnerable to predation by wolverines during the winter months, when they remain in or near the trees where they feed. During this time, few species of smaller mammals are available, for ground squirrels hibernate and microtine rodents are almost entirely subnivean in their activities. Among the latter, only red-backed voles (shown to be resistant to infection) move about rather freely on the surface of the snow. Red squirrels, Tamiasciurus hudsonicus (Erxleben), and flying squirrels, Glaucomys sabrinus (Shaw), remain active, but neither would be frequently captured by wolverines, nor has $T$. twitchelli been found in the large numbers of these and other common small rodents examined in Alaska. The porcupine appears to be the essential intermediate host of this cestode.

The adult $T$. twitchelli is probably host specific. Depending upon geographic location, the biotope of the wolverine may be shared in Alaska by any or all of the following mustelids : marten, Martes americana (Turton); ermine, Mustela erminea Linnaeus; least weasel, $M$. nivalis Linnaeus (cf Reichstein, 1957) ; mink, $M$. vison Schreber; and otter, Lutra canadensis (Schreber). T. twitchelli has never been recorded from any of these, nor do their cestodes ( $T$. mustelae and $T$. martis) parasitize the wolverine. None of the aforementioned species, however, is known to prey upon porcupines, so the apparent host specificity may be ecological rather than physiological. Another mustelid, the fisher, Martes pennanti (Erxleben), inhabits the boreal forest as far north as southern Yukon Territory and also preys upon porcupines (Quick, 1953; Hamilton and Cook, 1955). Possibly T. twitchelli will be found also in the fisher when its helminth parasites are better known.

A few attempts to infect other species of mustelids experimentally have been unsuccessful or inconclusive. A ferret, Mustela putorius Linnaeus, received a 126day-old larva with 18 scolices from an experimentally infected ground squirrel, but daily fecal examinations disclosed no eggs, and no cestodes were found when the animal was autopsied 55 days later. A second ferret received a larva with 10 scolices from the same source and likewise was uninfected when autopsied. A third ferret, given a single larva from the naturally infected porcupine, harbored no cestodes when it was killed after 22 days. A wild-trapped mink received a 241-day-old larva with 10 scolices from an experimentally infected porcupine. This mink died on the 7th day following exposure. Since it was not immediately examined, the 2 immature cestodes found, both about $10 \mathrm{~mm}$ long, were unidentifiable due to the effects of post-mortem degeneration of the intestine.

The adult cestode was reared only once under controlled conditions. One wolverine, a captive for about 2 years and known to be free of infection, was fed 2 larvae from a naturally infected porcupine. For 7 weeks before the experiment was terminated, fecal smears were examined daily for Taenia eggs with negative results. At autopsy, on the 66th day after exposure, 2 cestodes were found attached 
to the mucosa of the small intestine $1020 \mathrm{~mm}$ posterior to the pylorus. These measured $74 \mathrm{~mm}$ (106 segments) and $90 \mathrm{~mm}$ (113 segments) in length, respectively. The uterus was well developed in the terminal segments of both, but only the last segment of the larger strobila contained a few eggs. Although the time required for $T$. twitchelli to produce infective eggs was not determined, it probably is not less than 75 days.

\section{DISCUSSION}

Seven species of helminths have been recorded from wolverines in Alaska; viz, Alaria sp., Mesocestoides kirbyi, Taenia twitchelli, Trichinella spiralis, Malineus patens, Ascaris devosi, and Physaloptera torquata. Only one additional species has been reported from this mammal in North America: Price (1930) identified Soboliphyme baturini Petrov, 1930, from a wolverine killed in Montana, and Bezdek (1942) cited a record from a wolverine in Canada. I have identified $S$. baturini from other species of mustelids in Alaska (mink and marten), and suspect that it occurs here in wolverines also.

Several workers have mentioned the occurrence of Pseudamphistomum truncatum (Rudolphi, 1819) in wolverines in Eurasia (cf Price, 1932; Skriabin, 1950), and Hilgendorf and Paulicki (1870) reported Opisthorchis felineus (Rivolta, 1884). Erhardt (1935) believed that the latter infection had been acquired in the Hamburg Zoological Gardens where the animal died, rather than in northern Europe where it was captured. No cestodes have been reported from wolverines in Eurasia, but Spasskii et al (1952) and Machul'skii (1953) found 5 species of nematodes; viz, Capillaria putorii (Rudolphi, 1819), Molineus patens, Ascaris columnaris, Physaloptera sibirica, and Soboliphyme baturini. Some older records of uncertain status also exist (cf Stiles and Baker, 1935), but these have not been considered here.

Three of the helminths (T. spiralis, $M$. patens, and $S$. baturini) are now known to be holarctic in distribution. To these may be added Ascaris devosi, if later studies establish that the latter has been erroneously identified as $A$. columnaris in Eurasian mustelids. Another nematode, Capillaria putorii, although never validly recorded in North America, possibly is present (Read, 1949). Although there now is no contrary evidence, the existence of 2 species of Physaloptera in mustelids in boreal regions seems questionable.

The trematodes Pseudamphistomum truncatum and Opisthorchis felineus are found only in Eurasia, while the cestodes, Mesocestoides kirbyi and Taenia twitchelli, are known only from North America. The adult $T$. twitchelli is evidently host specific for the wolverine, a holarctic species. On the hypothesis that the larva also is host specific, at least ecologically, it follows that the cestode is restricted distributionally to North America. Erethizontid rodents first appeared in South America during the Oligocene, and Erethizon entered North America during Pliocene time over the Panama land bridge. Apparently, however, it had not extended its range far enough in North America to make its way into Eurasia during Pleistocene time (Simpson, 1945 ; Burt, 1958). It appears, then, that the host relationships of this cestode evolved in North America. If $T$. twitchelli were introduced into Eurasia, it seems doubtful that any mammalian species there would be both susceptible to infection by the larval cestode and preyed upon by wolverines 
to the degree necessary to ensure the perpetuation of the species.

$T$. twitchelli is one of the few species of Taenia known to reproduce by means of exogenous budding in the larval stage. The hexacanth embryos characteristically localize in the lungs of the intermediate host, and after about 2 weeks the larvae appear as translucent, more or less ovoid bodies measuring up to about $1.5 \mathrm{~mm}$ in length. At this time, they consist essentially of a thin cuticle enclosing delicate, reticular tissue, and closely resemble the larvae of other species of Taenia (e.g., $T$. pisiformis Bloch, 1780) at a comparable stage of development.

Intrapulmonary migration of the larvae evidently begins in porcupines at least as early as the 11th or 12th day following exposure, after which time each larva is found at the end of a leukocyte-filled tunnel with its anterior end in contact with ostensibly normal host tissue. The larvae, presumably, secrete a proteolytic enzyme enabling them to penetrate the tissue. From about the 16 th to the 25 th day, they break through the pulmonary pleura, escaping into the pleural cavities where their subsequent development takes place.

Since the emigrating larvae, when numerous, severely injure the lungs of the host, the onset of acute illness in some of the massively infected animals was taken to indicate the time of emergence of the larvae from the lungs. In those animals that died within about 24 hours after the first signs of acute respiratory disorder, the pleural cavities contained great numbers of larvae, while few remained within the lungs. The uniform size and state of development of those in the pleural cavities further indicate that the emigration of the larvae takes place over a relatively short period of time. In some animals, their emergence was apparently delayed, or perhaps prevented, by the severe inflammatory reaction they had evoked. For example, the pulmonary pleura was much thickened and fibrosed in a porcupine that died on the 24th day after exposure, and the majority of larvae had not yet emerged. Larvae were found also in the lungs of other hosts that had survived massive infections for a relatively long time, but none was found in the lungs of animals that had received light infections.

The maximum size normally attained by the larvae in the lungs of the host was not determined, since no animals were autopsied just at the time the larvae were beginning to emerge, but they evidently develop rapidly after they reach the pleural cavities. Ordinarily, the larvae do not become vesicular until after they enter the pleural cavities, although the change to this form eventually occurs even in those which never migrate from the lungs. The youngest larvae found in the pleural cavities were vesicular and had already produced buds. Irregularly spaced aggregations of cells in the vesicle wall indicate the sites of budding, and the buds are produced simply as evaginations of the vesicle wall. In some cases, invagination around the cellular aggregations occurs, but it is usually not seen until the buds are well defined; typically, such invagination is apical and results in the enclosure of the primordium of the scolex. Development is not uniform, and a single vesicle may have primordia of scolices in various stages of formation as well as buds of different sizes.

Soon after their appearance, the buds contain a persistent, delicate reticulum, usually represented in the mature larva by only a few strands of tissue. As the buds lengthen and become more or less pedunculate, the vesicle from which they originated is often largely obliterated and the scolex-bearing peduncles appear to 
be attached at a common point. The number of peduncles on mature larvae was found to range from 1 to 33, with an average of about 10 . Secondary buds are sometimes produced from the walls of earlier buds, and 2 scolices are sometimes found at the apex of a single peduncle. Endogenous budding from the wall of the primary vesicle is not uncommon. Although permanently enclosed by either the primary vesicle or by another bud into which it protrudes, the peduncles arising in this manner developed normally and produced fully formed scolices. Some pleomorphism in mature larvae appears to be related to host species. Larvae from lemmings, and sometimes from ground squirrels, had a somewhat spherical shape, with protruding short stalks, while those from muskrats and porcupines exhibited little trace of the original vesicle and possessed long peduncles. There is also a direct relationship between host size and the size of the larvae.

Secondary vesicles are sometimes produced by exogenous proliferation, beginning as evaginations of the wall of the primary vesicle and at first resembling typical buds. They then become constricted at the base, assume a discrete form, and usually become detached. Such secondary vesicles may show no signs of the primordia of scolices before becoming detached, but they later produce buds and apparently develop in the same way as the primary vesicles. The earliest formation of secondary vesicles observed was in a massively infected muskrat that died on the 60th day. Whether this process occurs regularly in the larval $T$. twitchelli is not known; however, mature larvae were also found with secondary vesicles still attached. In some cases, at least, small larvae with single scolices must have originated in this manner. Among other species of Taenia, only the cysticercus of $T$. crassiceps (Zeder, 1800) is known normally to produce secondary vesicles by means of exogenous proliferation.

The development of the mature larva from the primary vesicle of $T$. twitchelli appears to follow about the same pattern as described by Freeman (1956) for the multiscolex-type larva of $T$. mustelae Gmelin, 1790. In fact, some of the smaller larvae of $T$. twitchelli, such as those from lemmings, probably would be macroscopically indistinguishable from those of $T$. mustelae. The typical, mature larva of $T$. twitchelli, such as is usually found in porcupines, seems to resemble most closely the larva of T. endothoracicus Kirshenblat, 1948 (vide Dollfus, 1956; fig. 3). The larvae of the latter occur in various species of rodents and, according to Dubnitskii (1952), the adult cestode is a parasite of the red fox, Vulpes vulpes Linnaeus. A rather similar form, Taenia sp. indet., was described by Voge (1954) from the body cavity of Peruvian rodents.

Certain genera of the Taenia-group, all of which have morphologically similar adults, have been established primarily on the basis of larval characteristics. As various species become better known, however, it becomes increasingly apparent that the extent of morphological diversity, both intraspecific and interspecific, in their larval stages is often so great as to preclude their allocation to the existing genera. In my opinion, the establishment of taeniid genera based on the morphological characteristics of the larval stage is untenable, and it seems best to accept the genus Taenia in its widest application until such time that a critical revision of the group may be practicable. Although $T$. twitchelli was allocated to the genus Multiceps Goeze, 1782, by Clapham (1942), it is considered more appropriate to retain it in the genus Taenia, to which it was originally assigned by Schwartz (1924). 


\section{SUMMARY}

Seven species of helminths were collected from 80 wolverines autopsied in Alaska. Four species, viz, Alaria sp., Mesocestoides kirbyi Chandler, 1944, Ascaris devosi Sprent, 1952, and Physaloptera torquata Leidy, 1856, are recorded for the first time from this host, and a fifth, Molineus patens (Dujardin, 1845), for the first time from the wolverine in North America.

The life cycle of Taenia twitchelli Schwartz, 1924, a cestode apparently host specific for the wolverine, was completed experimentally, and the essential natural intermediate host is considered to be the porcupine, Erethizon dorsatum. Observations on host relationships and on the development and pathogenicity of the larval cestode are described. The original description of $T$. twitchelli has been supplemented and the taxonomic status of this species discussed.

\section{ACKNOWLEDGMENTS}

The writer is indebted to several trappers and guides who made available the wolverines studied. He wishes to thank especially Ward Gay, the late Max Shellabarger, and the Eskimos of Anaktuvuk Pass. Some material was provided also by biologists of the U. S. Fish and Wildlife Service. Edward Beeman collected the only naturally infected porcupine obtained. The Arctic Research Laboratory, Office of Naval Research, at Point Barrow, made possible some of the field work. The ascarids were identified by J. F. A. Sprent, University of Queensland, Australia, and the Physaloptera by Mrs. M. B. Chitwood, Agricultural Research Center, Maryland. James G. Bridgens, Independence Sanitarium and Hospital, Missouri, interpreted some of the earlier tissue sections, and Michael F. Beirne, Alaska Medical Laboratories, Anchorage, reviewed and confirmed the pathological findings. F. H. Fay and F. S. L. Williamson, of this Center, assisted with the field and laboratory work. Mrs. R. V. Rausch prepared the tissue sections and the illustrative material. This assistance is most gratefully acknowledged.

\section{ADDENDUM}

The writer has recently autopsied 28 additional wolverines taken in the Anaktuvuk Pass region, central Brooks Range, during the winter of 1958-59. The numbers of infected animals were as follows: Taenia twitchelli, 25 ; Ascaris, 11 ; Physaloptera, 1. No helminths were found in 2 animals.

\section{Literature Cited}

Bezdek, H. 1942 Studies on the nematode Soboliphyme baturini Petrow, 1930. Trans. Am. Micr. Soc. 61: 398-403.

Burt, W. H. 1958 The history and affinities of the recent land mammals of western North America. Zoogeography, Am. As. Adv. Sci., pp. 131-154.

Clapham, P. A. 1942 On identifying Multiceps spp. by measurement of the large hook. J. Helm. 20: 31-40.

Dollfus, R. Pн. 1956 Un hôte nouveau pour le cystique polycéphale de Taenia (Multiceps) endothoracicus Ja. D. Kirschenblatt, 1948. Bull. Soc. Path. Exot. 49: 281-284.

DubNitskiI, A. A. $1952 \mathrm{~K}$ rasshifrovke biologicheskogo tsikla tsestody Multiceps endothoracicus Kirschenblat, 1947. Dokl. Akad. Nauk SSSR 85: 1193-1195.

ERHARDT, A. 1935 Systematik und geographische Verbreitung der Gattung Opisthorchis R. Blanchard 1895, sowie Beiträge zur Chemotherapie und Pathologie der Opisthorchiasis. Ztschr. Parasit. 8: 188-225. 
Freeman, R. S. 1956 Life history studies on Taenia mustelae Gmelin, 1790 and the taxonomy of certain taenioid cestodes from Mustelidae. Can. J. Zool. 34: 219-242.

Hamilton, W. J. ANd Cook, A. H. 1955 The biology and management of the fisher in New York. N. Y. Fish and Game J. 2: 13-35.

Hilgendorf, F. and Paulicki, A. 1870 Ectasie des Ductus choledochus und der grösseren Gallengänge, bedingt durch Anhäufung von Plattwürmern bei einem Vielfrass, Gulo borealis. Berl. Klin. Wchnschr. 7: 566-567.

Machul'skit, S. N. 1953 Gel'minty kun'ikh Buriat-Mongol'skoi ASSR. Rabot. Gel'mintol. 75-Let. Skriabin, pp. 398-405.

McIntosh, A. 1938 Description of the adult stage of Taenia twitchelli Schwartz, 1924, from an Alaskan wolverine. Proc. Helm. Soc. Wash. 5: 14-15.

Price, E. W. 1930 The occurrence of Soboliphyme baturini Petrov in North America. J. Parasit. 17: 57.

1932 The trematode parasites of marine mammals. Proc. U. S. Nat. Mus., Art. 13 81: 1-68.

Quick, H. F. 1953 Occurrence of porcupine quills in carnivorous mammals. J. Mammal. 34: 256-259.

Rausch, R., Babero, B. B., Rausch, R. V. and Schiller, E. L. 1956 Studies on the helminth fauna of Alaska. XXVII. The occurrence of larvae of Trichinella spiralis in Alaskan mammals. J. Parasit. 42: 259-271.

Read, C. P. 1949 Studies on North American helminths of the genus Capillaria Zeder, 1800 (Nematoda) : I. Capillarids from mammals. J. Parasit. 35: 223-230.

Reichstein, H. 1957 Schädelvariabilität europäischer Mauswiesel (Mustela nivalis L.) und Hermeline (Mustela erminea L.) in Beziehung zu Verbreitung und Geschlecht. Ztschr. Säugetierk. 22: 151-182.

Schwartz, B. 1924 A new proliferating larval tapeworm from a porcupine. Proc. U. S. Nat. Mus., Art. 24 66: 1-4.

Simpson, G. G. 1945 The principles of classification and a classification of mammals. Bull. Am. Mus. Nat. Hist. 85.

Skriabin, K. I. 1950 Trematody zhivotnykh i cheloveka. Vol. 4. Moscow-Leningrad.

Spasskit, A. A., Ryzhikov, K. M. And Sudarikov, V. E. 1952 Gel'mintofauna dikikh mlekopitaiushchikh zony ozera Baikal. Trudy Gel'mint. Lab. Akad. Nauk SSSR 6: 85-113.

Sprent, J. F. A. 1952 On an Ascaris parasite of the fisher and marten, Ascaris dcvosi sp. nov. Proc. Helm. Soc. Wash. 19: 27-37. 1953 On the life history of Ascaris devosi and its development in the white mouse and the domestic ferret. Parasitology 42: 244-258.

Stiles, C. W. AND BAKer, C. E. 1935 Key-catalogue of parasites reported for Carnivora (cats, dogs, bears, etc.) with their possible public health importance. Nat. Inst. Health Bull. 163.

VoGE, M. 1954 Exogenous proliferation in a larval taeniid (Cestoda: Cyclophyllidea) obtained from the body cavity of Peruvian rodents. J. Parasit. 40: 411-413. 1955 North American cestodes of the genus Mesocestoides. Univ. Calif. Publ. Zool. 59: $125-156$. 